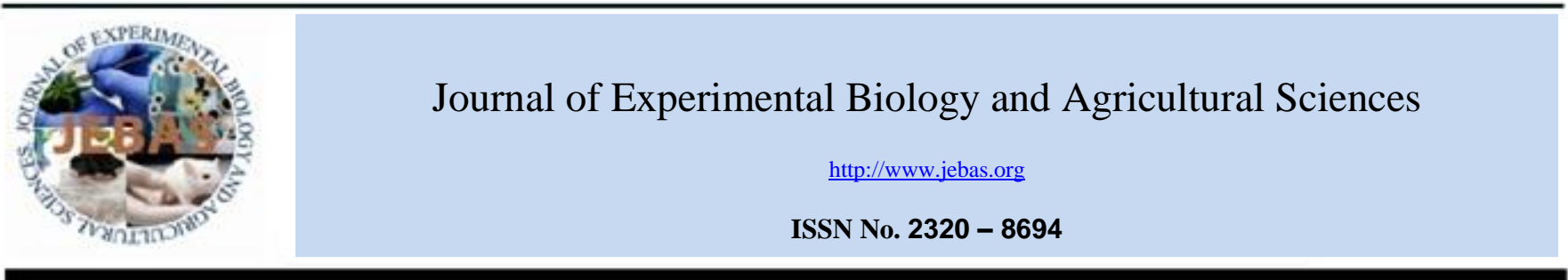

\title{
BIOCHEMICAL PROFILING OF PEEL AND POMACE OF ORGANICALLY GROWN Citrus reticulata AT DIFFERENT ALTITUDINAL GRADIENT
}

\author{
Pradhan A*, Sharma L* \\ Department of Horticulture, Sikkim University, $6^{\text {th }}$ Mile, Tadong, Gangtok,Sikkim,737102,India \\ Received - August 21, 2019; Revision - September 23, 2019; Accepted -September 28, 2019 \\ Available Online - October 15, 2019
}

DOI: http://dx.doi.org/10.18006/2019.7(5).442.451

\author{
KEYWORDS \\ Biochemical profiling \\ GCMS analysis \\ Oil yield, $P C A$ \\ Sikkim Mandarin
}

\begin{abstract}
This study aimed to elucidate biochemical profile of peel and pomace of Citrus reticulata grown organically at different altitudinal ranges of Sikkim Himalayas. Citrus peel and pomace are undoubtedly the good sources of many food ingredients, which are however discarded as waste. This study gives insight into the degree of availability of different biochemical in peel and pomace of fruits and also evaluated the effect of altitude and maturity stages on these biochemicals. Immature and mature fruit of C. reticulata from five altitude ranges $(800-1000 \mathrm{~m}, 1000-1200 \mathrm{~m}, 1200-1400 \mathrm{~m}, 1400-1600 \mathrm{~m}$ and $>1600 \mathrm{~m}$ ) of Sikkim were collected and subjected to juice extraction and air dried for proximate analysis. Essential oil was analysed using GC-MS. The mature fruits showed high reducing sugar, total sugar, non reducing sugar, TSS, TSS: acid, peel protein, peel and pomace crude fat, peel and pomace ash at all the altitudinal range compared to immature stage. Reducing sugar $(6.31 \%)$, total sugar $(8.69 \%)$, titrable acidity $(1.42 \%)$, TSS $\left(12.33^{\circ} \mathrm{Brix}\right)$, vitamin C $(40.40 \mathrm{mg} / 100 \mathrm{gm})$, peel and pomace crude fat $(19.07 \%)$, peel and pomace ash $(21.03 \%)$, Starch $(3.17 \%)$ was recorded highest at elevation range of $>1600 \mathrm{~m}$. The protein $(3.1 \%)$ content was however, highest at low elevation. The major constituent of peel oil was limonene. The limonene content was higher $(84.75 \%)$ at lower elevation (800-1000 m). Significant variations were seen on biochemical profile of peel and pomace of $C$. reticulata grown at different altitude ranges. Large number of physiological, biochemical and structural changes occur in fruits at different stages of maturity and during ripening. The variations in studied parameters are obvious at different stages of maturity.
\end{abstract}

* Corresponding author

E-mail: laxumans@gmail.com (Sharma L); anjanamalla@yahoo.com (Pradhan A)

Peer review under responsibility of Journal of Experimental Biology and Agricultural Sciences.

Production and Hosting by Horizon Publisher India [HPI] (http://www.horizonpublisherindia.in/).

All rights reserved.
All the articles published by Journal of Experimental Biology and Agricultural Sciences are licensed under a Creative Commons Attribution-NonCommercial 4.0 International License Based on a work at www.jebas.org.

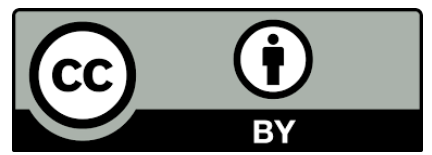




\section{Introduction}

Citrus reticulata, the commercial fruits in North Eastern India particularly Himalaya region of Sikkim India, is known for its use as table fruit or for processing. Fruit peel and pomace are the potential waste of citrus industry. The health hazard posed by improper disposal of waste peel led to find out alternate ways for waste valorization (Martín et al., 2013). Various researchers have mentioned about the application of fruit peel and pomace in food processing industries as by products (Makris et al., 2007; Helkar et al., 2016; Kodagoda \& Marapana, 2017). It has been reported that the peel yielded about $0.5-3 \mathrm{~kg}$ oil/tonne of fruit. Essential oil from peel bears natural flavours and fragrances and is widely used in food, daily used chemical products and health care industries (Sheng-min et al., 2012). Further, According to Pathak et al. (2017) this oil can be used in pharmaceuticals, confectioneries, cosmetics, alcoholic beverages and also for improving the shelf life of food. Citrus fruit is also a very good source of fibre, mineral and vitamins which are required for human growth and development (Sudha et al., 2017). Wadhwa \& Bakshi (2013) also established the nutritional value of pomace and suggested that it could be used as a source of animal feed.

Climatic conditions and the stage of the fruit development affects the physical and biochemical constituents of fruits. Accordingly, C. reticulata, has its various ecotypes such as Khasi mandarin, Darjeeling mandarin and Sikkim mandarin those are classified on the basis of their colour, quality and sugar-acid blend (Singh et al., 2016). In the mountainous region, particularly in the Sikkim, India it has grown organically in the altitudinal gradient ranging from $800 \mathrm{~m}$ to $1600 \mathrm{~m}$ from MSL, though scattered production also visible above $1600 \mathrm{~m}$. The aim of present study was to evaluate the effect of climatic conditions especially altitude on physical and chemical constituents of the citrus peel. Moreover, an organically grown mandarin fruit grown in this region was never assessed previously for the presence of such valuable parameters. This biochemical profiling would help in providing enough evidence for potential utilization of these discarded wastes.

\section{Materials and Methods}

Fruit samples were collected in 2017 from five different mandarin growing belts of Sikkim along the select altitudinal range viz: 800$1000 \mathrm{~m}, 1000-1200 \mathrm{~m}, 1200-1400 \mathrm{~m}, 1400-1600 \mathrm{~m}$ and $>1600 \mathrm{~m}$. Entire fruits were collected in two stages i.e. mature and immature stages. From the collected fruit samples, TSS, titrable acidity, vitamin C, Protein content, reducing sugar, total sugar were determined by following method describe by AOAC (2000). While, TSS/acid ratio was calculated by dividing TSS and titrable acidity. Likewise, peel starch, peel and pomace crude fat, crude fibre and ash were determined using Cleg (1956) method. Essential oil was extracted using clevenger apparatus as suggested by Hussain et al. (2008).

The triplicate data recorded for various attributes were subjected to analysis of variance (ANOVA) and expressed as mean. The means were compared using Duncan's multiple range tests (DMRT) using statistical software SPSS version 17.0 and $\mathrm{P}<0.05$ was taken as threshold for statistical significance. The constituents of the extracted oil from the peel was analysed using GC/MS-QP-2010 plus Ultra (Shimadzu company) using an Rtx-5 MS fused silica capillary column $(30 \mathrm{~m} \times 0.25 \mathrm{~m}$ i.d. film thickness $0.25 \mu \mathrm{m})$ and their groping was done by multivariate principle component analysis (PCA) and two way hierarchical analyses using JMP Pro 14 Software.

\section{Results and Discussions}

\subsection{Reducing sugar (\%)}

Estimated reducing sugars of immature and mature fruits collected from different range of elevations are presented in Table 1. The increasing altitudes have significant effect on the reducing sugar and it was reported highest at highest altitude. At mature stage, highest reducing sugar $(6.31 \%)$ was observed at an elevation $>1600 \mathrm{~m}$ and lowest at 800-1000 m (4.89\%). Similar trends were reported for immature fruits and highest reducing sugar $(4.72 \%)$

Table 1 Reducing sugar, total sugar and non reducing sugar in juice of Citrus reticulata fruit of mature and immature stage at different altitudinal range

\begin{tabular}{|c|c|c|c|c|c|c|}
\hline \multirow{2}{*}{ Parameters } & \multirow{2}{*}{ Stages } & \multicolumn{5}{|c|}{ Altitude range(m) } \\
\hline & & $800-1000$ & $1000-1200$ & $1200-1400$ & $1400-1600$ & $>1600$ \\
\hline \multirow{2}{*}{ Reducing sugar (\%) } & Mature & $4.89 \pm 0.11^{\mathrm{c}}$ & $5.18 \pm 0.07^{\mathrm{b}}$ & $6.05 \pm 0.02^{\mathrm{a}}$ & $6.07 \pm 0.03^{\mathrm{a}}$ & $6.31 \pm 0.09^{\mathrm{a}}$ \\
\hline & Immature & $4.08 \pm 0.06^{\mathrm{c}}$ & $4.39 \pm 0.13^{\mathrm{b}}$ & $4.63 \pm 0.01^{\mathrm{a}}$ & $4.67 \pm 0.01^{\mathrm{a}}$ & $4.72 \pm 0.02^{\mathrm{a}}$ \\
\hline \multirow{2}{*}{ Total sugar (\%) } & Mature & $7.04 \pm 0.04^{\mathrm{e}}$ & $7.12 \pm 0.01^{\mathrm{d}}$ & $7.27 \pm 0.02^{\mathrm{c}}$ & $7.99 \pm 0.01^{\mathrm{b}}$ & $8.69 \pm 0.02^{\mathrm{a}}$ \\
\hline & Immature & $5.03 \pm 0.01^{\mathrm{e}}$ & $5.25 \pm 0.01^{\mathrm{d}}$ & $6.03 \pm 0.02^{\mathrm{c}}$ & $6.32 \pm 0.02^{\mathrm{b}}$ & $6.91 \pm 0.01^{\mathrm{a}}$ \\
\hline \multirow{2}{*}{$\begin{array}{c}\text { Non reducing sugar } \\
(\%)\end{array}$} & Mature & $2.04 \pm 0.04^{\mathrm{ab}}$ & $1.84 \pm 0.004^{\mathrm{b}}$ & $1.16 \pm 0.13^{\mathrm{c}}$ & $1.82 \pm 0.04^{\mathrm{b}}$ & $2.26 \pm 0.11^{\mathrm{a}}$ \\
\hline & Immature & $0.89 \pm 0.03^{\mathrm{d}}$ & $0.82 \pm 0.04^{\mathrm{d}}$ & $1.33 \pm 0.01^{\mathrm{c}}$ & $1.57 \pm 0.08^{\mathrm{b}}$ & $2.08 \pm 0.02^{\mathrm{a}}$ \\
\hline
\end{tabular}

Given Data are mean of three replicates; mean \pm SE value followed by the different letter in same vertical column is significantly different according to Duncan's multiple range test $(P<0.05)$

Journal of Experimental Biology and Agricultural Sciences http://www.jebas.org 
Table 2 TSS, titrable acidity, TSS: acid and vitamin C in fruit juice of Citrus reticulata fruit of mature and immature stage at different altitudinal range

\begin{tabular}{|ccccccc|}
\hline \multirow{2}{*}{ Parameters } & Stages & $800-1000$ & $1000-1200$ & $1200-1400$ & $1400-1600$ & $>1600$ \\
& Mature & $9.93 \pm 0.66$ & $11.89 \pm 1.36$ & $11.97 \pm 0.93$ & $11.97 \pm 0.67$ & $12.33 \pm 0.77$ \\
\cline { 2 - 7 } TSS $\left({ }^{\circ} B\right)$ & Immature & $7.87 \pm 0.87$ & $9.43 \pm 0.99$ & $9.53 \pm 0.62$ & $10.32 \pm 0.51$ & $10.40 \pm 0.62$ \\
\cline { 2 - 7 } & Mature & $0.75 \pm 0.02^{\mathrm{c}}$ & $1.24 \pm 0.05^{\mathrm{b}}$ & $1.14 \pm 0.03^{\mathrm{b}}$ & $1.17 \pm 0.06^{\mathrm{b}}$ & $1.42 \pm 0.06^{\mathrm{a}}$ \\
\cline { 2 - 7 } TA & Immature & $1.61 \pm 0.07^{\mathrm{c}}$ & $1.79 \pm 0.03^{\mathrm{bc}}$ & $1.81 \pm 0.05^{\mathrm{b}}$ & $1.82 \pm 0.07^{\mathrm{b}}$ & $2.13 \pm 0.07^{\mathrm{a}}$ \\
\hline \multirow{2}{*}{ TSS:TA } & Mature & $13.25 \pm 0.67^{\mathrm{a}}$ & $9.68 \pm 1.44^{\mathrm{b}}$ & $10.48 \pm 0.87^{\mathrm{ab}}$ & $10.27 \pm 0.84^{\mathrm{b}}$ & $8.68 \pm 0.21^{\mathrm{b}}$ \\
\hline & Immature & $4.85 \pm 0.33^{\mathrm{a}}$ & $5.27 \pm 0.56^{\mathrm{b}}$ & $5.27 \pm 0.26^{\mathrm{b}}$ & $5.66 \pm 0.12^{\mathrm{ab}}$ & $4.88 \pm 0.32^{\mathrm{a}}$ \\
\hline $\begin{array}{l}\text { Vitamin C } \\
(\mathrm{mg} / 100 \mathrm{~g})\end{array}$ & Mature & $37.37 \pm 0.08^{\mathrm{d}}$ & $38.80 \pm 0.03^{\mathrm{c}}$ & $39.26 \pm 0.13^{\mathrm{b}}$ & $40.16 \pm 0.19^{\mathrm{a}}$ & $40.40 \pm 0.05^{\mathrm{a}}$ \\
\cline { 2 - 7 } & Immature & $47.00 \pm 0.07^{\mathrm{d}}$ & $48.80 \pm 0.07^{\mathrm{c}}$ & $52.00 \pm 0.04^{\mathrm{b}}$ & $52.90 \pm 0.28^{\mathrm{a}}$ & $53.02 \pm 0.19^{\mathrm{a}}$ \\
\hline
\end{tabular}

Given Data are mean of three replicates; mean $\pm S E$ value followed by the different letter in same vertical column is significantly different according to Duncan's multiple range test $(P<0.05)$

was estimated at $>1600 \mathrm{~m}$ altitudes while lowest $(4.08 \%)$ was reported at $800-1000 \mathrm{~m}$ altitude, though this difference is not significantly different as reported for mature fruits. At maturity, there is usually a depolymerisation of polysaccharides and conversion of fruit starch to sugar. Trend of increased reducing sugar with altitude in Khasi mandarin was reported by Deka et al (2006) and Deshmukh et al. (2016). Likewise Yadav (2014) reported $3.68 \%, 3.37 \%, 3.63 \%$ and $3.06 \%$ reducing sugar in Kinnow mandarin, Emperor, Clementine Monreal and Clementine Denule, respectively.

\subsection{Total sugar $(\%)$}

Total sugar also showed similar increasing trends as observed in reducing sugar (Table 1); it was estimated in the range of $7.04 \%$ to $8.69 \%$ in mature and 5.03 to $5.3 \%$ in immature fruits. The present range of total sugar is higher than the previous studies conducted on citrus in India, this variation might be because of crop and location difference. Yadav (2014) reported $5.36 \%$ total sugar in citrus cultivar Sanguinella moschata, $6.18 \%$ in cv. Vagnalia apirino, 5.88 $\%$ in Ruby red and $4.67 \%$ in Duncan. Higher Total sugar in the mature stage attributes to the depolymerisation of polysaccharides and conversion of fruit starch sugar (Deshmukh et al., 2016).

\subsection{Non reducing sugar $(\%)$}

Non reducing sugar was $2.38 \%$ at elevation $>1600 \mathrm{~m}$ and $2.15 \%$ at a range of $800-1000 \mathrm{~m}$ in mature fruits. Likewise in immature stage $2.18 \%$ was found to be highest at $>1600 \mathrm{~m}$ and $0.89 \%$ was lowest at 1000-1200 m altitudes (Table 1). Similarly, Yadav (2014) have also reported that non-reducing sugar content in the range of $1.66 \%$ in Kinnow to $2.98 \%$ in Sweet Orange cv. Vagnalia apirino while studying dozens of cultivars. The non-reducing sugar content increased from mature green to full ripen stage and such increase might be due to break down of starch and there after formation of non-reducing sugar (Moneruzzaman et al., 2008).

\subsection{Titrable acidity $(\%)$}

The sampled fruit showed variation in the titrable acidity content $(\mathrm{p}<$ 0.05 ) at both stage of maturity (Table 2). Juice extracted from mature fruits collected from altitude $>1600 \mathrm{~m}(1.42 \%)$ showed significantly higher $(\mathrm{p}<0.05)$ titrable acidity, followed by $1000-1200 \mathrm{~m}(1.24 \%)$ and $800-1000 \mathrm{~m}(0.749 \%)$.Whereas in immature stage, acidity was higher compared to mature stage $(2.13 \%)$ at $>1600 \mathrm{~m}$ followed by $1000-1200 \mathrm{~m}(1.79 \%)$. Generally, acidity of fruit decreased as fruit approaches towards maturity (Grewal et al., 2000). Further, Kishore et al. (2010) showed variation in acidity from $1.74 \%$ to $1.34 \%$ in $C$. reticulata grown in Sikkim, which is found to be quite similar with the present study. Further, Hangsing et al. (2016) performed study in khasi mandarin based on the age of tree and reported $0.81 \%$ acidity in 10-20 years old Khasi mandarin tree, $0.76 \%$ acidity in 21-30 years, $0.78 \%$ acidity in $31-40$ years and $0.73 \%$ acidity in $>40$ years old Khasi mandarin tree.

\subsection{Vitamin C $\left(\mathrm{mg}^{100 \mathrm{gm}^{-1}}\right)$}

Vitamin $C$ in mature fruits was recorded highest (40.40 $\mathrm{mg} / 100 \mathrm{~g})$ in the samples taken from higher altitude $(>1600 \mathrm{~m})$ and the lowest $(37.37 \mathrm{mg} / 100 \mathrm{~g})$ at an elevation range of 800 $1000 \mathrm{~m}$. In immature fruits, it was recorded to the tune of 53.02 $\mathrm{mg} / 100 \mathrm{~g}$ at $>1600 \mathrm{~m}$ and $52.9 \mathrm{mg} / 100 \mathrm{~g}$ at $1400-1600 \mathrm{~m}$ (Table 2). The increased Vitamin $\mathrm{C}$ is due to more citric acid which is positively correlated to the synthesis of ascorbic acid A decrease in the ascorbic acid content at lower altitude could be attributed to the reason that there is enzymatic loss of $\mathrm{L}$ ascorbic acid, where it is converted to 2-3 dioxy-L.gluconic acid (Mapson, 1970). 


\subsection{TSS $\left({ }^{\circ} \mathrm{B}\right)$}

The mean data of total soluble solids (TSS) was recorded highest in samples collected from $>1600 \mathrm{~m}$ altitude at mature stage $\left(12.33^{\circ}\right.$ Brix $)$ and immature stage $\left(10.40^{\circ}\right.$ Brix $)$ which is followed by $1200-1400 \mathrm{~m}$ altitude $\left(11.97^{\circ} \mathrm{Brix}\right)$ in mature and $1400-1600 \mathrm{~m}$ altitude with $10.32^{\circ}$ Brix as presented in Table 2 . The results are in corroboration with the finding of Yadav (2014) in which Kagzi lime showed $13.86^{\circ} \mathrm{B}$ and $10.01^{\circ} \mathrm{B}$ in Baramasi lime. However, Ruby Red was recorded with $8.39^{\circ} \mathrm{B}$ and Duncan with $4.74^{\circ} \mathrm{B}$. Further there was variation from 4.55 to $7.40^{\circ}$ Brix in Kagzi kalan lemon cultivar while comparing two years data (Yadav, 2014). Richardson et al. (1997) reported that relative level of different sugars and acids changes during citrus fruit development appears to be influenced by temperature. At higher altitude the fruits maturity is slower than the lower altitude, in such case, TSS is increased due to accumulation of sugar, increased dehydration of the fruits and high light intensity (Rokaya et al., 2016).

\subsection{TSS : Acid}

The TSS: acid ratio is presented in Table 2. At altitudinal range of 800-1000 m, TSS: acid ratio was found highest (13.25) at mature stage whereas it was highest (5.67) at 1400-1600 m altitude in immature staged fruit. Lowest ratio was recorded for mature (8.68) and in immature (4.86) stages respectively at > $1600 \mathrm{~m}$ altitude. The increase in TSS/acidity may be due to high minimum and maximum temperature during that period which accelerates increase in TSS:acid ratio. Similarly, Deshmukh et al. (2016) suggested that decrease in minimum and maximum temperature at higher altitude drop the TSS: acid ratio. At higher altitude the ratio is seen to be lesser than the lower altitude, it is probably due to the more formation of acidic compound due to degradation of reducing sugars at later stage of the maturity, since the fruit maturity is late in higher altitude than the lower altitude. Higher ratio at low altitude is due to more loss of acidity due to normal respiration and conversion to other metabolites (El-otmani \& Coggins, 1991).

\subsection{Peel and pomace crude fat (\%)}

In mandarin peel, crude fat was highest in mature stage (19.07\%) compared to immature stage $(11.39 \%)$ at altitude $>1600 \mathrm{~m}$. Whereas, the lowest value was $5.48 \%$ and $2.33 \%$, in mature and immature peel collected from 800-1000 m respectively (Table 3). Peace \& Happiness (2017) considered that mandarin peel is a better source for dietary fat/oil in mature stage compared to immature one. In Citrus maxima peel extract contain $9.74 \%$ crude fat, which showed dissimilarity with the findings of present study. However, orange peels obtained from unripe oranges analysed by Adewole et al. (2014) for fat content and reported $14.35 \%$ fat which is in agreement with the present research. Likewise, Osarumwense et al. (2013) and Uraku (2015) reported $10 \%$ and $10.34 \%$ peel crude fat respectively in $C$. sinensis and these results are in corroboration with the findings of present study.

Mandarin pomace contains appreciable amount of crude fat. It

Table 3 Effect of altitude and stages on peel and pomace of crude fat, crude fiber and ash content of Citrus reticulata fruit of mature and immature at different altitudinal range.

\begin{tabular}{|cc|ccccc|}
\hline \multirow{2}{*}{ Parameters } & Stages & \multicolumn{5}{c|}{ Altitude range (m) } \\
& & $800-1000$ & $1000-1200$ & $1200-1400$ & $1400-1600$ & $>1600$ \\
\hline \multirow{2}{*}{ Peel Crude fat (\%) } & Mature & $5.48 \pm 0.02^{\mathrm{c}}$ & $17.60 \pm 0.08^{\mathrm{b}}$ & $17.98 \pm 0.51^{\mathrm{ab}}$ & $18.01 \pm 0.54^{\mathrm{ab}}$ & $19.07 \pm 0.27^{\mathrm{a}}$ \\
\cline { 2 - 7 } & Immature & $2.33 \pm 0.02^{\mathrm{c}}$ & $8.78 \pm 0.58^{\mathrm{b}}$ & $10.44 \pm 0.26^{\mathrm{a}}$ & $10.44 \pm 0.54^{\mathrm{a}}$ & $11.39 \pm 0.43^{\mathrm{a}}$ \\
\hline \multirow{2}{*}{ Pomace Crude fat (\%) } & Mature & $3.45 \pm 0.02^{\mathrm{c}}$ & $5.09 \pm 0.09^{\mathrm{b}}$ & $5.13 \pm 0.25^{\mathrm{b}}$ & $10.89 \pm 0.25^{\mathrm{a}}$ & $10.93 \pm 0.56^{\mathrm{a}}$ \\
\cline { 2 - 7 } & Immature & $2.54 \pm 0.13^{\mathrm{c}}$ & $4.72 \pm 0.01^{\mathrm{b}}$ & $6.44 \pm 0.04^{\mathrm{a}}$ & $6.85 \pm 0.21^{\mathrm{a}}$ & $6.89 \pm 0.20^{\mathrm{a}}$ \\
\hline \multirow{2}{*}{ Peel Crude fibre (\%) } & Mature & $16.03 \pm 0.78^{\mathrm{e}}$ & $18.12 \pm 0.02^{\mathrm{d}}$ & $20.47 \pm 0.09^{\mathrm{c}}$ & $23.96 \pm 0.28^{\mathrm{b}}$ & $27.44 \pm 0.29^{\mathrm{a}}$ \\
\cline { 2 - 7 } & Immature & $11.24 \pm 0.37^{\mathrm{c}}$ & $11.32 \pm 0.35^{\mathrm{c}}$ & $15.73 \pm 0.09^{\mathrm{b}}$ & $16.23 \pm 0.16^{\mathrm{b}}$ & $21.39 \pm 0.54^{\mathrm{a}}$ \\
\hline \multirow{2}{*}{ Pomace Crude fibre (\%) } & Mature & $17.87 \pm 0.12^{\mathrm{b}}$ & $20.65 \pm 0.09^{\mathrm{a}}$ & $20.669 \pm 0.62^{\mathrm{a}}$ & $21.52 \pm 0.29^{\mathrm{a}}$ & $21.76 \pm 0.45^{\mathrm{a}}$ \\
\cline { 2 - 7 } & Immature & $9.87 \pm 0.04^{\mathrm{b}}$ & $11.59 \pm 0.62^{\mathrm{b}}$ & $11.74 \pm 0.11^{\mathrm{b}}$ & $15.09 \pm 0.29^{\mathrm{a}}$ & $15.16 \pm 1.33^{\mathrm{a}}$ \\
\hline \multirow{2}{*}{ Peel Ash (\%) } & Mature & $15.61 \pm 0.62^{\mathrm{d}}$ & $17.91 \pm 0.21^{\mathrm{c}}$ & $17.93 \pm 0.36^{\mathrm{c}}$ & $24.16 \pm 0.17^{\mathrm{b}}$ & $27.44 \pm 0.02^{\mathrm{a}}$ \\
\cline { 2 - 7 } & Immature & $10.97 \pm 0.29^{\mathrm{d}}$ & $11.14 \pm 0.01^{\mathrm{d}}$ & $15.30 \pm 0.16^{\mathrm{c}}$ & $17.70 \pm 0.32^{\mathrm{b}}$ & $21.40 \pm 0.07^{\mathrm{a}}$ \\
\hline \multirow{2}{*}{ Pomace Ash (\%) } & Mature & $17.40 \pm 0.18^{\mathrm{c}}$ & $20.57 \pm 0.09^{\mathrm{a}}$ & $18.54 \pm 0.04^{\mathrm{b}}$ & $21.03 \pm 0.58^{\mathrm{a}}$ & $20.4 \pm 0.08^{\mathrm{a}}$ \\
\cline { 2 - 7 } & Immature & $5.10 \pm 0.13^{\mathrm{d}}$ & $13.67 \pm 0.88^{\mathrm{b}}$ & $10.74 \pm 0.25^{\mathrm{c}}$ & $19.07 \pm 0.49^{\mathrm{a}}$ & $13.65 \pm 0.96^{\mathrm{b}}$ \\
\hline
\end{tabular}

Given Data are mean of three replicates; mean $\pm S E$ value followed by the different letter in same vertical column is significantly different according to Duncan's multiple range test $(P<0.05)$ 
varied from $3.45 \%$ to $10.93 \%$ in the elevation range of $800-1000$ $\mathrm{m}$ to $>1600 \mathrm{~m}$ altitude respectively in mature fruits. Whereas, it ranges from $2.54 \%$ to $6.89 \%$ in immature stage at same altitude as mentioned previously. The low-fat content at immature stage makes it an ideal component in weight reducing diets. The value of fat content are in disagreement with the value obtained from $C$. sinensis $(10.34 \%)$ and orange peel $(8.70 \%)$ by Uraku (2015) and Feumba et al. (2016) respectively.

\subsection{Peel and pomace crude fibre (\%)}

Variation in crude fibre content was reported (Table 3) and highest crude fibre content was recorded in mature fruits collected from an elevation >1600 m (27.44\%) followed by $1400-1600 \mathrm{~m}(23.96 \%)$. Whereas the least amount of crude fibre content was observed at $800-1000 \mathrm{~m}$ altitude $(16.03 \%)$. However, in immature stage, crude fibre content was $21.40 \%$ at $>1600 \mathrm{~m}$ altitude while lowest was recorded at $800-1000 \mathrm{~m}$ altitude $(11.24 \%)$. Peel of the mature stage fruit showed significantly higher fibre percentage compared to immature stages irrespective of range of altitude. The crude fibre content is almost double than that found in sweet orange (12.79\%) by Oyebola et al. (2017) and Oikeh et al. (2013). Fruit fibre is considered as better in quality than plant fibre due to higher total and soluble fibre content, water and oil holding capacity, low caloric value and phytic acid (Figuerola et al., 2005). Hence, mandarin peel could be incorporated as an ingredient during processing of foods and livestock feeds as low-cost nutritional dietary supplement to livestock and human beings for sustainable disposal of orange rind residues (Oyebola et al., 2017). Altitudinal based variation was also observed for pomace crude fibre. Pomace fibre was as high $(21.76 \%)$ in mature fruits at an altitude range of $>1600 \mathrm{~m}$ and low $(15.16 \%)$ in immature stage. This fibre conten was higher than maize, soybean oilcake and sunflower meal with value of 2.70, 3.30-7.00 and 14.00\% respectively (ISIRI, 2002).

\subsection{Peel and pomace ash $(\%)$}

Ash content in the peel was estimated in the range between 15.61 to $27.44 \%$ at mature and 10.97 to $21.40 \%$ at immature stage (Table 3). An increase in elevation also increases the value which is higher than the finding of ISIRI (2002). Therefore, with the value of ash reported in this study, Sikkim mandarin peel may be suitable for animal feeds. In the range of $1400-1600 \mathrm{~m}$ altitude, pomace ash was about $21.03 \%$ in mature and $19.07 \%$ in immature fruits. In previous study, Ahmed et al. (2016) reported that pomace ash in mature and immature Citrus aurantiifolia was in the range of 5.92 and $5.71 \%$ and it was higher $(3.51 \%$ and $3.33 \%)$ than the orange peel (Citrus sinensis).

\subsection{Peel and pomace Starch(\%)}

In mature fruit stage, highest starch content in peel $(3.17 \%)$ was recorded at elevation range $>1600 \mathrm{~m}$ and that of lowest $(1.23 \%)$ at 800-1000 m elevation. Whereas, in immature stage $3.40 \%$ starch content was reported at $>1600 \mathrm{~m}$ altitude while it was reported $1.83 \%$ in $800-1000 \mathrm{~m}$ altitude (Table 4 ). Result of study revealed that starch content was significantly higher in immature stage as compared to mature one. The peel starch of this fruit is higher than the commonly used fruits such as Durian (2.55\%) and Mango peel (1.14\%) (Wanlapa et al., 2015). Pomace starch was found less than the peel starch, it was estimated in the range of 1.06 to $1.82 \%$ in mature stage and in the range of $1.95 \%$ to $4.20 \%$ in immature stage.

\subsection{Peel and pomace protein(\%)}

At low elevation $(800-1000 \mathrm{~m})$ protein content in peel was found higher in mature $(3.10 \%)$ and immature fruits $(2.65 \%)$. Whereas lowest protein content $(2.30 \%)$ was observed in peel at 1000-1200 $\mathrm{m}$ in mature $(2.32 \%)$ and immature $(1.87 \%)$ stages as presented in

Table 4 Protein and starch in peel and pomace of Citrus reticulata fruit of mature and immature stage at different altitudinal range

\begin{tabular}{|ccccccc|}
\hline \multirow{2}{*}{ Parameters } & Stages & \multicolumn{5}{c|}{ Altitude range (m) } \\
& & $800-1000$ & $1000-1200$ & $1200-1400$ & $1400-1600$ & $>1600$ \\
\hline \multirow{2}{*}{ Peel starch (\%) } & Mature & $1.23 \pm 0.02^{\mathrm{d}}$ & $2.52 \pm 0.01^{\mathrm{c}}$ & $3.03 \pm 0.07^{\mathrm{b}}$ & $3.05 \pm 0.05^{\mathrm{b}}$ & $3.17 \pm 0.01^{\mathrm{a}}$ \\
\cline { 2 - 7 } & Immature & $1.83 \pm 0.01^{\mathrm{d}}$ & $2.31 \pm 0.12^{\mathrm{c}}$ & $2.33 \pm 0.02^{\mathrm{c}}$ & $2.63 \pm 0.03^{\mathrm{b}}$ & $3.39 \pm 0.05^{\mathrm{a}}$ \\
\hline \multirow{2}{*}{ Pomace Starch (\%) } & Mature & $1.06 \pm 0.01^{\mathrm{b}}$ & $1.14 \pm 0.12^{\mathrm{b}}$ & $1.79 \pm 0.15^{\mathrm{a}}$ & $1.76 \pm 0.08^{\mathrm{a}}$ & $1.82 \pm 0.02^{\mathrm{a}}$ \\
\cline { 2 - 7 } & Immature & $1.95 \pm 0.01^{\mathrm{c}}$ & $3.64 \pm 0.02^{\mathrm{b}}$ & $3.86 \pm 0.03^{\mathrm{ab}}$ & $4.17 \pm 0.23^{\mathrm{a}}$ & $4.20 \pm 0.01^{\mathrm{a}}$ \\
\hline \multirow{2}{*}{ Peel Protein $(\%)$} & Mature & $3.10 \pm 0.03^{\mathrm{a}}$ & $2.32 \pm 0.04^{\mathrm{d}}$ & $2.77 \pm 0.03^{\mathrm{b}}$ & $2.63 \pm 0.04^{\mathrm{c}}$ & $3.05 \pm 0.04^{\mathrm{a}}$ \\
\cline { 2 - 7 } & Immature & $2.65 \pm 0.01^{\mathrm{a}}$ & $1.87 \pm 0.03^{\mathrm{c}}$ & $2.23 \pm 0.03^{\mathrm{b}}$ & $2.26 \pm 0.01^{\mathrm{b}}$ & $2.23 \pm 0.01^{\mathrm{b}}$ \\
\hline \multirow{2}{*}{ Pomace Protein $(\%)$} & Mature & $1.90 \pm 0.04^{\mathrm{c}}$ & $2.25 \pm 0.04^{\mathrm{b}}$ & $1.79 \pm 0.03^{\mathrm{c}}$ & $3.00 \pm 0.03^{\mathrm{a}}$ & $1.81 \pm 0.04^{\mathrm{c}}$ \\
\cline { 2 - 7 } & Immature & $2.34 \pm 0.01^{\mathrm{a}}$ & $2.27 \pm 0.01^{\mathrm{b}}$ & $2.30 \pm 0.01^{\mathrm{b}}$ & $2.11 \pm 0.01^{\mathrm{d}}$ & $2.19 \pm 0.01^{\mathrm{c}}$ \\
\hline
\end{tabular}

Given Data are mean of three replicates; mean \pm SE value followed by the different letter in same vertical column is significantly different according to Duncan's multiple range test $(P<0.05)$

Journal of Experimental Biology and Agricultural Sciences http://www.jebas.org 
Table 5 Oil yield in peel of mature and immature fruits of Citrus reticulata L. at different altitudinal range.

\begin{tabular}{|cccc|}
\hline Sl No. & Altitude range $(\mathrm{m})$ & Mature (Oil Yield) & Stages \\
\hline 1 & $800-1000$ & $1.48 \pm 0.08^{7 \mathrm{c}}$ & $1.49 \pm 0.07^{\mathrm{c}}$ \\
\hline 2 & $1000-1200$ & $1.83 \pm 0.07^{\mathrm{b}}$ & $1.95 \pm 0.25^{\mathrm{b}}$ \\
\hline 3 & $1200-1400$ & $1.84 \pm 0.06^{\mathrm{b}}$ & $1.97 \pm 0.12^{\mathrm{b}}$ \\
\hline 4 & $1400-1600$ & $2.03 \pm 0.06^{\mathrm{b}}$ & $2.06 \pm 0.06^{\mathrm{b}}$ \\
\hline 5 & $>1600$ & $2.40 \pm 0.12^{\mathrm{a}}$ & $2.50 \pm 0.11^{\mathrm{a}}$ \\
\hline
\end{tabular}

Given Data are mean of three replicates; mean \pm SE value followed by the different letter in same vertical column is significantly different according to Duncan's multiple range test $(P<0.05)$
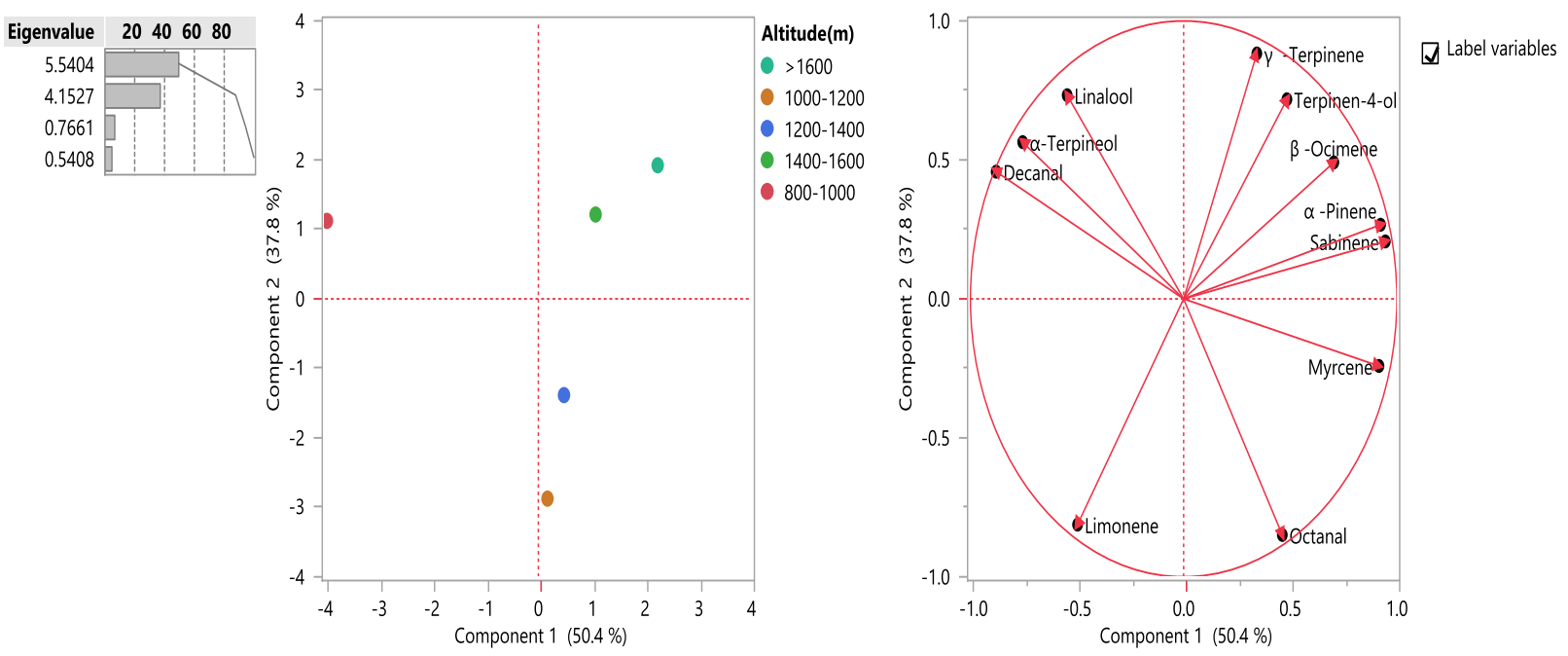

Figure 1Variation in area (\%) in compounds at immature stage based on GCMS analysis - Principal Component Analysis

Table 4. According to the Ahmed et al. (2016) content was found less than some other citrus fruits such as kinnow (5.21\%) and grape fruit $(6.24 \%)$. The protein content reported in present study was lower than that reported by El-ghfar et al. (2016), which was in the range of $6.39 \%$ (air oven drying) to $7.09 \%$ (fresh, control) in orange peel and that of lemon with $7.06 \%$ (air oven drying) $11.53 \%$ (fresh, control).

\subsection{Oil yield and chemical analysis of essential oil}

The data regarding oil yield is depicted in table 5. It showed that oil yield was higher in immature fruit $(2.50 \%)$ as compared to mature $(2.40 \%)$ at $>1600 \mathrm{~m}$ altitude this was followed by $2.03 \%$ and $2.06 \%$ in mature and immature stage at $1400-1600 \mathrm{~m}$ altitude respectively.

In immature peel, total 11 compounds were analysed by GC-MS analysis (Table 6). Major compounds present in this stage are $\alpha$ -
Pinene, Sabinene, Myrcene, Octanal, Limonene, $\beta$-Ocimene, $\gamma$ Terpinene, Linalool, Terpinen-4-ol, $\alpha$-Terpineol and Decanal. The main component was limonene with concentrations of $87.45 \%$ of the oil at $800-1000 \mathrm{~m}$ altitude, $88.58 \%$ at $1000-1200 \mathrm{~m}$ altitude, $87.85 \%$ at $1200-1400 \mathrm{~m}$ altitude, $84.23 \%$ at $1400-1600 \mathrm{~m}$ altitude and $84.72 \%$ at $>1600 \mathrm{~m}$ altitude. It showed that highest value in 1000-1200 m altitude. It was followed by $\gamma$-Terpinene with 5.16 $\%, 3.56 \%, 5.24 \%, 6.28 \%$ and $6.33 \%$ at various altitudes viz: $800-1000 \mathrm{~m}, 1000-1200 \mathrm{~m}, 1200-1400 \mathrm{~m}, 1400-1600 \mathrm{~m}$ and $>1600$ $\mathrm{m}$ respectively. Likewise, linalool and myrcene showed percent as $1.88 \%$ and $1.51 \%, 0.66 \%$ and $1.61 \%, 1.27 \%$ and $1.66 \%, 1.17 \%$ and $1.61 \%$ and $1.43 \%$ and $1.65 \%$ at $800-1000 \mathrm{~m}, 1000-1200 \mathrm{~m}$, $1200-1400 \mathrm{~m}, 1400-1600 \mathrm{~m}$ and $>1600 \mathrm{~m}$ respectively (Figure 1).

The mature stage fruit also had the presence of 11 compounds analysed by GC-MS analysed (Table 6). The main component was limonene with $85.21 \%, 86.06 \%, 84.72 \%, 74.71 \%$ and $85.96 \%$ at $800-1000 \mathrm{~m}, 1000-1200 \mathrm{~m}, 1200-1400 \mathrm{~m}, 1400-1600 \mathrm{~m}$ and 
Table 6 GC-MS analysis of peel and pomace of Citrus reticulata in mature and immature stages at different altitudinal range (Expressed as area \%).

\begin{tabular}{|c|c|c|c|c|c|c|}
\hline \multirow{2}{*}{ Parameters } & \multirow{2}{*}{ Stages } & \multicolumn{5}{|c|}{ Altitude(m) } \\
\hline & & $800-1000$ & $1000-1200$ & $1200-1400$ & $1400-1600$ & $>1600$ \\
\hline \multirow{2}{*}{$\alpha$-Pinene } & Mature & $0.52 \pm 0.11$ & $0.52 \pm 0.01$ & $0.60 \pm 0.09$ & $0.61 \pm 0.01$ & $0.63 \pm 0.13$ \\
\hline & Immature & $0.47 \pm 0.02$ & $0.63 \pm 0.13$ & $0.79 \pm 0.04$ & $0.89 \pm 0.01$ & $0.89 \pm 0.04$ \\
\hline \multirow{2}{*}{ Sabinene } & Mature & $0.46 \pm 0.04$ & $0.65 \pm 0.24$ & $0.83 \pm 0.27$ & $0.53 \pm 0.08$ & $0.62 \pm 0.09$ \\
\hline & Immature & $0.03 \pm 0.03$ & $0.63 \pm 0.15$ & $0.57 \pm 0.05$ & $0.75 \pm 0.02$ & $1.18 \pm 0.25$ \\
\hline \multirow{2}{*}{ Myrcene } & Mature & $1.55 \pm 0.05$ & $1.53 \pm 0.03$ & $1.09 \pm 0.41$ & $1.43 \pm 0.01$ & $1.58 \pm 0.12$ \\
\hline & Immature & $1.51 \pm 0.01$ & $1.61 \pm 0.03$ & $1.66 \pm 0.03$ & $1.61 \pm 0.01$ & $1.65 \pm 0.02$ \\
\hline \multirow{2}{*}{ Octanal } & Mature & $0.39 \pm 0.04$ & $0.49 \pm 0.13$ & $0.29 \pm 0.14$ & $0.35 \pm 0.18$ & $0.36 \pm 0.16$ \\
\hline & Immature & $0.15 \pm 0.07$ & $0.23 \pm 0.01$ & $0.19 \pm 0.04$ & $0.17 \pm 0.05$ & $0.18 \pm 0.05$ \\
\hline \multirow{2}{*}{ Limonene } & Mature & $85.21 \pm 2.99$ & $86.06 \pm 2.28$ & $84.72 \pm 2.41$ & $74.71 \pm 0.99$ & $85.96 \pm 2.91$ \\
\hline & Immature & $87.45 \pm 0.11$ & $88.58 \pm 0.51$ & $87.85 \pm 0.78$ & $84.22 \pm 0.05$ & $84.71 \pm 0.73$ \\
\hline \multirow{2}{*}{$\beta$-Ocimene } & Mature & $0.04 \pm 0.02$ & $0.07 \pm 0.03$ & $0.09 \pm 0.01$ & $0.07 \pm 0.02$ & $0.06 \pm 0.03$ \\
\hline & Immature & $0.04 \pm 0.04$ & $0.06 \pm 0.01$ & $0.07 \pm 0.01$ & $0.07 \pm 0.03$ & $0.16 \pm 0.08$ \\
\hline \multirow{2}{*}{$\gamma$-Terpinene } & Mature & $0.41 \pm 0.26$ & $2.93 \pm 1.37$ & $4.65 \pm 0.49$ & $3.99 \pm 0.23$ & $4.45 \pm 0.25$ \\
\hline & Immature & $5.16 \pm 0.29^{\mathrm{a}}$ & $3.60 \pm 1.08$ & $5.24 \pm 0.27$ & $6.28 \pm 0.05$ & $6.33 \pm 0.16$ \\
\hline \multirow{2}{*}{ Linalool } & Mature & $1.60 \pm 0.04$ & $2.79 \pm 1.88$ & $2.29 \pm 0.69$ & $3.08 \pm 3.03$ & $2.64 \pm 1.77$ \\
\hline & Immature & $1.88 \pm 0.03$ & $0.66 \pm 0.32$ & $1.27 \pm 0.09$ & $1.17 \pm 0.65$ & $1.43 \pm 0.32$ \\
\hline \multirow{2}{*}{ Terpinen-4-ol } & Mature & $0.24 \pm 0.02$ & $0.38 \pm 0.25$ & $0.28 \pm 0.09$ & $0.69 \pm 0.56$ & $0.29 \pm 0.14$ \\
\hline & Immature & $0.24 \pm 0.04$ & $0.23 \pm 0.07$ & $0.16 \pm 0.02$ & $0.36 \pm 0.03$ & $0.40 \pm 0.04$ \\
\hline \multirow{2}{*}{$\alpha$-Terpineol } & Mature & $0.28 \pm 0.04$ & $0.40 \pm 0.30$ & $0.28 \pm 0.06$ & $0.53 \pm 0.40$ & $0.40 \pm 0.25$ \\
\hline & Immature & $0.36 \pm 0.04$ & $0.20 \pm 0.05$ & $0.16 \pm 0.02$ & $0.23 \pm 0.04$ & $0.24 \pm 0.01$ \\
\hline \multirow{2}{*}{ Decanal } & Mature & $0.18 \pm 0.02$ & $0.14 \pm 0.06$ & $0.21 \pm 0.02$ & $0.23 \pm 0.01$ & $0.30 \pm 0.06$ \\
\hline & Immature & $0.25 \pm 0.03$ & $0.11 \pm 0.06$ & $0.123 \pm 0.07$ & $0.13 \pm 0.01$ & $0.13 \pm 0.08$ \\
\hline
\end{tabular}

$>1600 \mathrm{~m}$ respectively. Amongst these, maximum limonene was found in $1000-1200 \mathrm{~m}$ altitude with $86.10 \%$. It was followed by linalool and myrcene with area percent of $3.08 \%$ and 1.58 at 1400 $1600 \mathrm{~m}$ and $>1600 \mathrm{~m}$ altitude accordingly. Results of present finding revealed that limonene content of $C$. reticulata was higher than the reported by Colecio-Juárez et al. (2012) in Citrus limetta with $70 \%$ (limonene) and myrcene $(1.31 \%)$. Further, limonene $(69.90 \%)$, linalool $(1.10 \%)$ and myrcene $(3.27 \%)$ of area percent were found in Citrus reticulata (Kamal et al., 2011).

\subsection{Principal Component Analysis (PCA)}

\subsubsection{GC-MS signature of peel oil of mature and immature fruit}

The multivariate principal component analysis was carried out employing JMP Pro14 software for complete GC-MS signature of all the analysed compounds. The analysis covered $88.20 \%$ with PC-1 and PC-2 (Figure1). The PC analysis resulted in three group of altitude variation in Sikkim Mandarin (Figure 1), where in $>1600 \mathrm{~m}$ and 1400-1600 m altitude could be grouped in one category (Group 1) based on the abundance of $\gamma$-terpinene ( 6.34 $\%$ and $6.28 \%$ ), terpinen-4-ol ( $0.40 \%$ and $0.36 \%), \beta$-ocimene $(0.16 \%$ and $0.07 \%), \alpha$-pinene $(0.89 \%$ and $0.89 \%)$, sabinene $(1.18 \%$ and $0.75 \%)$

While, $800-1000 \mathrm{~m}$ could be grouped as separate (Group 2) category with high amount of linalool $(1.88 \%), \alpha$ - terpineol $(0.36 \%)$ and decanal $(0.25 \%)$ besides the PCA had given out another major group (Group 3) in which 1000-1200 m and 1200$1400 \mathrm{~m}$ was grouped. This group of altitude have moderate amount of reported compounds listed earlier as myrcene (1.61 and $1.66 \%$ ), octanal $(0.23 \%$ and $0.19 \%)$ and limonene $(88.58 \%$ and $87.85 \%)$. 

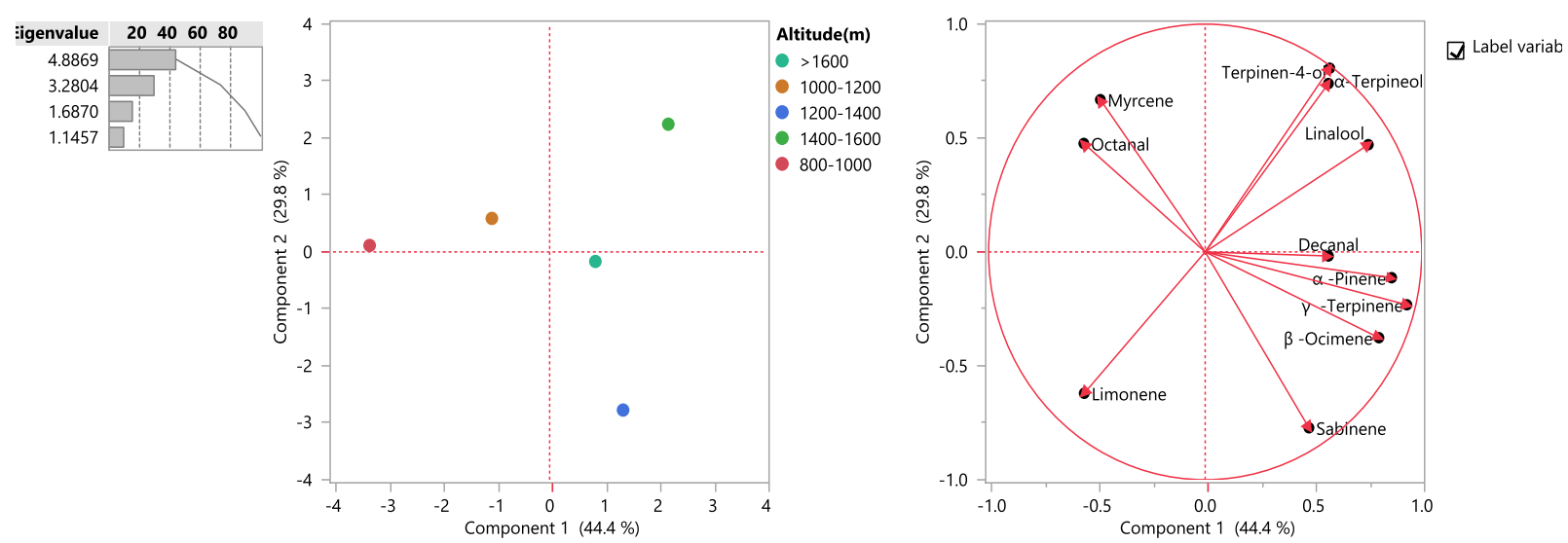

Figure 2 Variation in area (\%) in compounds at mature stage based on GCMS analysis Principal Component Analysis (Likewise, Group 3 showed 1400-1600 m and 1200-1400 m altitude which had $\alpha$-pinene (0.61\% and $0.60 \%)$, $\gamma$-terpinene (3.99\% and $4.65 \%)$, $\beta$-ocimene $(0.07$ $\%$ and $0.09 \%$ ), sabinene ( $0.53 \%$ and $0.83 \%$ ) and also with high amount of same element which were categorized in Group 2).

Mature stage of Sikkim mandarin essential oil of peel from area percent showed in three groups as Group 1, Group 2 and Group 3 (Figure 2). It covered $74.2 \%$ area in PC -1 and PC-2. In group 1, $800-1000 \mathrm{~m}$ and $1000-1200 \mathrm{~m}$ altitude was categorized as one which is having myrcene $(1.55 \%$ and $1.53 \%)$ and octanal $(0.39$ and 0.49 $\%)$ compound. Likewise, at $>1600 \mathrm{~m}$ was placed in Group 2 due to abundance of compound like terpinen-4-ol (2.64\%), $\alpha$ - terpineol $(0.40 \%)$, linalool $(2.64 \%)$ and decanal $(0.30 \%)$. Likewise, Group 3 showed 1400-1600 m and 1200-1400 m altitude which had $\alpha$-pinene $(0.61 \%$ and $0.60 \%), \gamma$-terpinene (3.99\% and $4.65 \%), \beta$-ocimene $(0.07 \%$ and $0.09 \%)$, sabinene $(0.53 \%$ and $0.83 \%)$ and also with high amount of Limonene (74.77\% and $84.22 \%$ ).

In conclusion, biochemical parameters assessed during the present study were affected by the change in altitude. However, it was noted that the peel had high level of proximate parameters and the oil with high level of valuable constituents across all the elevation range. The level of all the biochemical constituents give better insight that the discarded peel and pomace can be utilized for different industries including the flavour, aroma, animal feed and disinfectant.

\section{Acknowledgements}

Authors acknowledge the farmers of five different altitudes in four districts of Sikkim who had provided the fruits. Facilities provided by Department of Horticulture, Sikkim University for this study is highly acknowledged.

\section{Conflict of Interest}

Authors would hereby like to declare that there is no conflict of interests that could possibly arise.

\section{References}

Adewole E, Adewumi DF, Jonathan J, Fadaka AO (2014) Phytochemical constituents and proximate analysis of orange peel. Journal of Advanced Botany and Zoology 1: 2348-7313.

AOAC (2000) Official methods of analysis. 17th Edition. The association of official analytical chemists. Gaithersburg, MD, USA.

Ahmed MHAE, Ibrahim HM, Hassan IM, Fattah AAA, Mahmoud MH (2016) Peels of lemon and orange as value-added ingredients: Chemical and antioxidant properties. International Journal of Current Microbiology and Applied Sciences 5: 777-794.

Cleg KM (1956) The application of anthrone reagent to the estimation of starch in cereals. Journal of Science and Food Agriculture 7: 40-44.

Deka BC, Sharma S, Borah SC (2006) Post-harvest management practices for shelf-life extension of Khasi mandarin. Indian Journal of Horticulture 63: 251-500.

Deshmukh N, Patel R, Rymbai H (2016) Fruit maturity and associated changes in Khasi Mandarin (Citrus reticulata) at different altitudes in humid tropical climate. Indian Journal of Agricultural Sciences 86: 854-900.

El-ghfar MHAA, Ibrahim MH, Hassan IM, Fattah AAA, Mahmoud MH (2016) Peels of Lemon and Orange as ValueAdded Ingredients: Chemical and Antioxidant Properties. International Journal of Current Microbiology and Applied Sciences 5: 777-794. 
EI-Otmani M, Coggins, Jr. CW (1991) Growth regulator effect on retention of quality of stored citrus fruits. Scientia Horticulturae 45, 261-272.

Feumba DR, Ashwini RP, Ragu SM (2016) Chemical composition of some selected fruit peels. European Journal of Food Science and Technology 4: 12-21.

Figuerola F, Hurtado ML, Estevez AM, Chiffelle I, Asenjo F (2005) Fibre concentrates from apple pomace and citrus peel as potential fibre sources for food enrichment. Food Chemistry 91: 395- 401 .

Grewal AG, Hafiz IA, Chaudhary AH, Khan MI, Chaudhary MI (2000) Quality estimation during marketing of kinnow and feutrell's early. International Journal of Agriculture and Biology 2: 328-330.

Hangsing H, Mathew B, Kalita DC (2016) Performance of Khasi mandarin in Garo hills of Meghalaya. International Journal of Environmental Science and Technology $5: 3213$ - 3223.

Helkar PB, Sahoo AK, Patil NJ (2016) Review. Food Industry ByProducts used as a Functional Food Ingredients. International Journal of Waste Resources 6:248.

Hussain AI, Anwar F, Sherazi STH, Przybylski R (2008) Chemical composition, antioxidant and antimicrobial activities of basil (Ocimum basilicum) essential oils depends on seasonal variations. Food Chemistry 108: 986-995.

ISIRI(2002) Sunflower meal specification and test methods in feed stuff. Institute of Standards and Industrial Research of Iran, Second Revision, No. 322.

Kamal GM, Anwar FAI, Hussain NS, Ashraf MY (2011) Yield and chemical composition of Citrus essential oils as affected by drying pre-treatment of peels. International Food Resources Journal 18: 1275-1282.

Kishore K, Kumar A, Rahman H, Pandey B (2010) Physicochemical and sensorial attributes of Sikkim mandarin (Citrus reticulata). Indian Journal of Agricultural Sciences 80: 164-170.

Kodagoda KHGK, Marapana RAUJ (2017) Utilization of fruit processing by-products for industrial applications: A review. International Journal of Food Sciences and Nutrition 2: 24-30.

Makris DP, Boskou G, Andrikopoulos NK (2007) Polyphenolic content and in vitro antioxidant characteristics of wine industry and other agri-food solid waste extracts. Journal of Food Composition and Analysis 20: 125-132.
Mapson LW (1970) The Bio-Chemistry of Fruits and Their Products. In: Hulme AC (Ed.), Vitamins in Fruits, Vol. 1, Academic Press, London, Pp. 369-384.

Colecio-Juárez MC, Rubio-Núñez RE, Botello-Álvarez JE, Martínez-González GM, Navarrete-Bolaños JL, Jiménez-Islas H (2012) Characterization of volatile compounds in the essential oil of sweet lime (Citrus limetta Risso). Chilean Journal of Agricultural Research 72: 275-280.

Martin MA, Fernandez R, Serrano A (2013).Semi-continuous anaerobic co digestion of orange peel waste and residual glycerol derived from biodiesel manufacturing. Waste Management 33:1633-1639.

Moneruzzaman KM, Hossain ABMS, Sani W, Saifuddin M (2008) Effect of Stages of Maturity and Ripening Conditions on the Biochemical Characteristics of Tomato. American Journal of Biochemistry and Biotechnology $4: 336-344$.

Oikeh EI, Oriakhi, Kand Omoregie ES (2013) Proximate analysis and phytochemical screening of Citrus sinensis fruit wastes. The Bioscientist 1:164-170.

Osarumwense PO, Okunrobo LO, Uwumarongie-Ilor EG (2013) Phytochemical screening, proximate and elemental analysis of Citrus sinensis peels (1.) Osbeck. Jouranl of Applied Science and Environmental Management 17:47-50.

Oyebola OO, Agboola SO, Olabode OA, Ayoola PO (2017) Analysis of physical and chemical composition of sweet orange (Citrus sinensis) peels. International Journal of Environment, Agriculture and Biotechnology 2(4): 2201-2206.

Pathak PD, Mandavgane SA, Kulkarni BD (2017) Fruit peel waste: characterization and its potential uses. Current Science 113: 444-454.

Peace NA, Happiness CA (2017) Nutrient, phyto chemical, and anti nutrient composition of Citrus maxima fruit juice and peel extract. Food Science and Nutrition 6: 653-658.

Richardson CA, McAneney KJ, Dawson TE (1997) Carbohydrate dynamics in kiwifruit. Journal of Horticultural Sciences 72: 907-917.

Rokaya PR, Barah DR, Gautam DM, Shrestha AR, Paudyal KP (2016) Effect of altitude and maturity stages on quality attributes of mandarin (Citrus reticulata Blanco). American Journal of Plant Sciences 7: 958-966.

Singh AK, Meetei T, Singh BK, Mandal N (2016) Khasi mandarin: its importance, problems and prospects of cultivation in Northeastern Himalayan region. International Journal of Agriculture, Environment and Biotechnology 9: 573-592. 
Sheng-min LU, Ying-Chun S, Yang Y (2012) Research progress on extraction and refining of citrus essential oil. Institute of food science, Zhejiang academy of agricultural sciences, Hangzhou, China.

Sudha A, Amutha R, Kavusik T (2017) Analysis of bioactive compounds in citrus fruit peels. International Journal of Scientific Research and Reviews 6: 1-10.

Uraku AJ (2015) Nutritional potential of Citrus sinensis and Vitis vinifera peels. Journal of Advances in Medical and Life Sciences 3 : 2348-2940.

Wanlapa S, Wachirasir IK, Sithisam-ang D, Suwannatup T (2015)

Potential of selected tropical fruit peels as dietary fibre in functional foods. International Journal of Food Properties 18: 1306-1316.

Wadhwa M, Bakshi M (2013) Utilization of fruit and vegetable wastes as livestock feed and as substrates for generation of other value-added products. In: Makkar HPS (Ed.), All India Coordinated Research Project on Improvement of feed resources and nutrient utilization in raising animal production. RAP publication, Pp 1-69.

Yadav V (2014) Variability and character association studies of citrus species and genotypes under subtropical conditions of H.P. M.Sc.Thesis submitted to the Dr Yashwant Singh Parmar University of Horticulture and forestry, Nauni. Solan, India. 